\title{
Lignocellulosic wastes of Carya illinoinensis (Juglandaceae) inhibit germi- nation and seedling development of Lactuca sativa (Asteraceae)
}

\author{
Neiva Bremm ${ }^{\mathrm{a}}$, Rodrigo Ferraz $\operatorname{Ramos}^{\mathrm{bc} *} \oplus$, Nestor Bremm ${ }^{\mathrm{b}} \oplus$, Cristiano Belléc $\oplus$, \\ Tiago Edu Kaspary ${ }^{d} \bullet$, Tatiane Chassot ${ }^{a}$, Débora Leitzke Betemps ${ }^{a}(\mathbb{C}$ \\ a Universidade Federal da Fronteira Sul, Brasil \\ b Universidade Federal de Santa Maria, Brasil \\ c Instituto Phytus, Brasil \\ d Instituto Nacional de Investigación Agropecuaria del Uruguay, Uruguay \\ *Autor correspondente (rodrigoferrazramos@gmail.com)
}

\section{N F O}

\section{Keyworks}

allelopathic effect vegetable waste pecan walnut
Palavras-chaves efeito alelopático resíduo vegetal noz pecan

\begin{abstract}
A B S T R A C T
Resíduos lignocelulósicos de Carya illinoinensis (Juglandaceae) inibem a germinação e o desenvolvimento de plântulas de Lactuca sativa (Asteraceae)

The study evaluated the effect of Carya illinoinensis plant extracts on lettuce seed germination and development. Experiment was carried out in a completely randomized experimental design with five treatments and five replications. Plant extracts were prepared from the dry ground vegetable waste. The concentration was adjusted to $10 \% \mathrm{~m} \cdot \mathrm{v}^{-1}$. The treatments were classified into: heterogeneous pruning residues (HPR), leaves residues (LR), epicarp residues (ER), mesocarp residues (MR), and control treatment (CT, 100\% water). The variables evaluated were: first germination count $(\mathrm{GP} 4 \%)$, final germination count (GP7\%), germination speed index (GSI), germination inhibition (PGI), frequency of abnormal seedlings (FAS), root length (RL), shoot length (SL), and total length of seedling (TLS). Extracts obtained from residues of $C$. illinoinensis decreased the lettuce seed germination, but their effect depends on the plant tissue (e.g. leaf, epicarp or mesocarp) used at production of plant extracts. Plant extracts from HPR and MR do not result in drastic allelochemical effects. Aqueous extracts from LR and ER reduced significantly the seed germination and the normal development of lettuce seedlings, with an absolute reduction in germination of $90.2 \%$ and $79.2 \%$, respectively. Only plant extracts from leaf residues and epicarp residues from $C$. illinoinensis inhibit the germination and seedling development of L. sativa.
\end{abstract}

\section{R E S U M O}

O estudo avaliou o efeito de extratos de plantas de Carya illinoinensis na germinação e no desenvolvimento de sementes de alface. $\mathrm{O}$ experimento foi conduzido em delineamento inteiramente casualizado com cinco tratamentos e cinco repetições. Extratos de plantas foram preparados a partir de resíduos vegetais secos. A concentração foi ajustada para $10 \% \mathrm{~m} \cdot \mathrm{v}^{-1}$. Os tratamentos foram classificados: resíduos de poda heterogêneos (HPR), resíduos de folhas (LR), resíduos de epicarpo (ER), resíduos de mesocarpo (MR) e tratamento controle (CT, 100\% água). As variáveis avaliadas foram: primeira contagem de germinação (GP4\%), contagem final de germinação (GP7\%), índice de velocidade de germinação (GSI), inibição de germinação (PGI), frequência de plântulas anormais (FAS), comprimento de raiz (RL), comprimento de parte aérea (SL) e comprimento total da muda (TLS). Os extratos obtidos a partir dos resíduos de C. illinoinensis diminuem a germinação das sementes de alface, mas seu efeito depende do tecido vegetal (por exemplo, folha, epicarpo ou mesocarpo) utilizado na produção dos extratos vegetais. Os extratos vegetais de HPR e MR não resultam em efeitos alelopáticos drásticos. Os extratos aquosos de LR e ER reduziram significativamente a germinação das sementes e o desenvolvimento normal das plântulas de alface, com redução absoluta na germinação de $90,2 \%$ e $79,2 \%$, respectivamente. Apenas extratos vegetais de resíduos de folhas e resíduos de epicarpo de C. illinoinensis inibem a germinação e o desenvolvimento de plântulas de L. sativa. 


\section{INTRODUCTION}

Lignocellulosic plant wastes represent a material with high potential for use in forestry, horticulture and floriculture. Lignocellulosic residues can be used as ingredients to compose alternative substrates in the production of forest and vegetable seedlings (Severino et al. 2006). These alternative substrates are generated by the disposal of fibrous agro-industrial waste. As an example, there is sugarcane bagasse, wooded rice parboiled husk, coconut fiber, pine bark, castor bark and tree pruning residues (Junior and Magalhães, 2010; Lima et al. 2011; Rodrigues et al. 2016; Bundchen et al. 2019; Vieira et al. 2019)

Pecan tree (Carya illinoinensis) is a plant that has lignocellulosic wastes with potential application in the formulation of substrates for seedling production. The fruits of this species need constant pruning, result in a large volume of lignocellulosic waste (Wolff and Medeiros 2017). Pecan tree vegetable wastes can have adequate physical and chemical characteristics and can be used as substrate, either in mixtures with other substrates or alone (Fermino et al. 2015). However, fresh plant wastes (non-composted) may have allelochemical substances (e.g. bioactive compound such as quinoid, phenolic and flavonoids compounds) (Islam and Widhalm, 2020). These substances, produced by secondary metabolism, can cause deleterious effects on seeds germination or initial seedling development (Aslam et al., 2017; Feng et al., 2017; Rehman et al., 2019). Newly, it has been shown that aqueous extracts of pecan tree wastes can inhibit lettuce (Lactuca sativa L.) seed germination (Klein et al., 2017). However, the individual allelochemical effects of each lignocellulosic component (leaves, fruit peel, heterogeneous pruning residues) of pecan tree wastes on seed germination remains unknown.

Thusly, the objective of our research was to evaluate the allelochemical effects of heterogeneous pruning residues, leaves, epicarp and mesocarp of pecan fruit on seed germination and lettuce seedling development.

\section{MATERIAL AND METHODS}

Vegetable remains of pecan tree pruning were collected in an orchard, located in São Paulo das Missões, Rio Grande do Sul State, Brazil

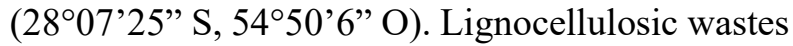
were separated into: a) heterogeneous pruning residues (branches and buds), b) leaves, c) epicarp of fruits, and d) mesocarp of fruits. Samples were collected immediately after tree pruning. Vegetable residues were disinfected in a $2.5 \% \mathrm{NaCl}$ solution for $1 \mathrm{~min}$, followed by washing in distilled water.
The samples were dried at $60^{\circ} \mathrm{C}$ to constant weight. Samples were milled, sieved (5.0 and $1.0 \mathrm{~mm})$, and stored in aluminum foil coated glass vials. Samples were placed in a dark room at environmental temperature. Plant extracts (VE) were prepared from the dry ground vegetable waste. Vegetal waste was added in beckers containing distilled water $(25$ $\pm 2.0^{\circ} \mathrm{C}$ ), with concentration adjusted to $10 \% \mathrm{~m} \mathrm{v}^{-}$ 1. Thus, the plant extracts were obtained by static maceration for $10 \mathrm{~min}$, using distilled water as an extractor.

The experiment was carried out in a completely randomized experimental design, with five replications of 25 seeds per repetition. Lettuce seeds (Lactuca sativa L.) was submitted at the following treatments: a) heterogeneous pruning residues (HPR; $10 \% \mathrm{~m} \mathrm{v}^{-1}$ ), b) leaves residues (LR; $\left.10 \% \mathrm{~m} \mathrm{v}^{-1}\right), \mathrm{c}$ ) epicarp residues (ER; $\left.10 \% \mathrm{~m} \mathrm{v}^{-1}\right), \mathrm{d}$ ) mesocarp residues (MR; $10 \% \mathrm{~m} \mathrm{v}^{-1}$ ), and e) control treatment (CT; $100 \%$ water). The seeds were added in transparent boxes containing two sheets-paper moistened with $10 \mathrm{ml}$ each solution. The boxes were incubated in a Biological Oxygen Demand (BOD Luca-161/03, Brazil) at $25 \pm 2.0^{\circ} \mathrm{C}$, with 12 $\mathrm{h}$ photoperiod for up to seven days.

The variables evaluated were: first germination count (GP4 \%) and final germination count (GP7 $\%$ ), according with the Brazilian Rules for Seed Testing Brasil (2009) and Wylot et al. (2019). Germination speed index (GSI) was avaluated according to Groth et al. (2020) and germination inhibition (PGI \%) according Santos et al. (2007). Frequency of abnormal seedlings (FAS\%); root length $(\mathrm{RL} \mathrm{cm})$; shoots length $(\mathrm{SL} \mathrm{cm})$ and total length of seedling (TLS cm) were avaluated according Nasser et al. (2019).

The experiment was performed twice time and the repetition results were used to calculate averages and standard error $( \pm)$ using Microsoft Office Excel 2007 (Microsoft $^{\circledR}$ ) software.

Data were submitted to analysis of variance (ANOVA) and normality test by Shapiro-Wilk at $5 \%$ significance. The mean values were compared using the Scott-Knott test at 95\% confidence level. Statistical analysis was performed using the ExpDes.pt package (Ferreira et al., 2018) in environment R (R Core Team, 2019). Data that did not show normality of residues were submitted to analysis of variance by Kruskal-Wallis one-way and multiple comparison of treatments with Bonferroni correction using the Agricolae package (Mendiburu, 2019). The correlation matrix was generated using the "corrplot" package (Wei and Simko, 2017). The data were also submitted to a principal component analysis (PCA) through the Stats Package (R Core Team, 2019). 


\section{RESULTS}

Plant extracts (ER, LR and MR) reduced strongly the lettuce seed germination at first germination count (GP4), with a reduction of $86 \%$, $79 \%$ and $16 \%$, respectively, compared to TC (Table 1). In the final germination count, the solution from of ER and LR reduced approximately 90 and $79 \%$ the lettuce seed germination, respectively (Table 1). All plant extracts partially inhibited seed germination with reduction rate of $95 \%, 84 \%, 23 \%$ and $14 \%$ for extracts ER, LR, MR and HPR, respectively. All plant extracts significantly reduced the germination speed index (GSI), being in descending order $\mathrm{ER}<\mathrm{LR}<\mathrm{MR}<\mathrm{HPR}<\mathrm{CT}$.

Table 1 - First germination count (GP4), final germination count (GP7), percentage of germination inhibition (PGI) and germination speed index (GSI) of Lactuca sativa L. seeds submitted to different plant extracts of Carya illinoinensis (Wangenh.) K. Koch.

\begin{tabular}{ccccc}
\hline Treatment & GP4 (\%) & GP7 (\%) & PGI (\%) & GSI \\
\hline CT $^{1}$ & $86.4 \pm 7.55 \mathrm{a}^{2}$ & $94.4 \pm 3.71 \mathrm{a}^{2}$ & $0.0 \pm 0.00 \mathrm{~b}^{3}$ & $10.5 \pm 1.08 \mathrm{a}^{2}$ \\
ER & $0.0 \pm 0.00 \mathrm{c}$ & $4.0 \pm 1.79 \mathrm{~d}$ & $95.5 \pm 2.07 \mathrm{a}$ & $0.2 \pm 0.08 \mathrm{c}$ \\
MR & $70.4 \pm 12.04 \mathrm{~b}$ & $77.6 \pm 11.14 \mathrm{~b}$ & $22.7 \pm 10.88 \mathrm{~b}$ & $8.7 \pm 1.54 \mathrm{~b}$ \\
HPR & $83.2 \pm 4.63 \mathrm{a}$ & $87.2 \pm 3.67 \mathrm{a}$ & $14.5 \pm 3.73 \mathrm{~b}$ & $9.2 \pm 1.08 \mathrm{~b}$ \\
LR & $7.2 \pm 6.25 \mathrm{c}$ & $15.2 \pm 7.53 \mathrm{c}$ & $84.3 \pm 7.86 \mathrm{a}$ & $1.0 \pm 0.61 \mathrm{c}$ \\
\hline $\boldsymbol{P \text { -value }}$ & $<0.0001$ & $<0.0001$ & 0.0005 & $<0.0001$ \\
CV\% & 32.76 & 26.10 & 32.44 & 38.11 \\
\hline
\end{tabular}

${ }^{1} \mathrm{CT}=$ control treatment; ER $=$ epicarp residues; $\mathrm{MR}=$ mesocarp residues; HPR $=$ heterogeneous pruning residues; and LR $=$ leaves residues.

${ }^{2}$ Means and standard error $( \pm)$ with the same letter are not differ by Scott-Knott test $(\mathrm{P}<0.05)$.

${ }^{3}$ Analysis of variance by Kruskal-Wallis one-way and multiple comparison of treatments with Bonferroni correction.

The date observed for use of ER and LR extracts demonstrate a reduction of the $71.6 \%$ and $47.8 \%$ for root length (RL) compared to the control, respectively (Table 2). Similar effect was observed for the CMH variable, which both ER and LR extracts reduced the hypocotyl (SL) length by
$100 \%$ and $86.4 \%$, respectively. Consequently, ER and LR also reduced seedlings length by $83.1 \%$ and $64.3 \%$ when compared to the control (Table 2). All plant extracts resulted in an increase in the frequency of abnormal seedlings (FAS), where ER treatment resulted in $100 \%$ of abnormal seedlings.

Table 2 - Root length (RL), shoots length (SL), total length of seedling (TLS) and frequency of abnormal seedlings (FAS) of Lactuca sativa L. seeds submitted to different plant extracts of Carya illinoinensis (Wangenh.) K. Koch.

\begin{tabular}{ccccc}
\hline Treatment & RL & SL & TLS & FAS \\
\cline { 2 - 5 } & \multicolumn{2}{c}{----- o $^{----}$} \\
\hline CT $^{\mathbf{1}}$ & $6.7 \pm 2.14 \mathrm{a}^{3}$ & $4.4 \pm 0.49 \mathrm{a}^{2}$ & $11.2 \pm 2.60 \mathrm{a}^{3}$ & $39.1 \pm 1.73 \mathrm{e}^{3}$ \\
ER & $1.9 \pm 0.80 \mathrm{~b}$ & $0.0 \pm 0.00 \mathrm{~d}$ & $1.9 \pm 0.80 \mathrm{~b}$ & $100.0 \pm 0.00 \mathrm{a}$ \\
MR & $4.6 \pm 0.22 \mathrm{ab}$ & $3.6 \pm 0.29 \mathrm{~b}$ & $8.2 \pm 0.42 \mathrm{a}$ & $73.9 \pm 1.82 \mathrm{c}$ \\
HPR & $5.9 \pm 0.57 \mathrm{a}$ & $4.6 \pm 0.54 \mathrm{a}$ & $10.5 \pm 0.87 \mathrm{a}$ & $64.8 \pm 1.71 \mathrm{~d}$ \\
LR & $3.5 \pm 0.90 \mathrm{ab}$ & $0.6 \pm 0.38 \mathrm{c}$ & $4.0 \pm 1.10 \mathrm{~b}$ & $87.2 \pm 4.00 \mathrm{~b}$ \\
\hline $\boldsymbol{P}$-value & 0.01102 & $<0.0001$ & 0.00081 & 0.00016 \\
CV\% & 56.1 & 32.87 & 43.53 & 6.88
\end{tabular}

${ }^{1} \mathrm{CT}=$ control treatment; ER $=$ epicarp residues; $\mathrm{MR}=$ mesocarp residues; HPR = heterogeneous pruning residues; and LR $=$ leaves residues.

${ }^{2}$ Means and standard error $( \pm)$ with the same letter are not significantly different at $\mathrm{P}<0.05$ by Scott-Knott test.

${ }^{3}$ Analysis of variance by Kruskal-Wallis one-way and multiple comparison of treatments with Bonferroni correction.

Each evaluated variable resulted in a significant correlation with the other variables. The percentage of inhibition of germination showed a positive correlation $(r=0.82)$ with the frequency of abnormal seedlings (Figure 1A). These two variables (PGI and FAS) showed a negative correlation with all other variables. Five variables contributed similarly $(\sim 13 \%)$ to the variation in the first principal component (Figure 1B). Only two variables (RL and TLS) contributed above the expected variation (red dashed line) for the second principal component (Figure 1C). The first principal component (x-axis) contributed $85 \%$ of the total variation, while the second component (y- 
axis) contributed 9.1\% (Figure 1D). Following the same trajectory of the correlation analysis, the principal component analysis demonstrated that the variables FAS and PGI are closely related and
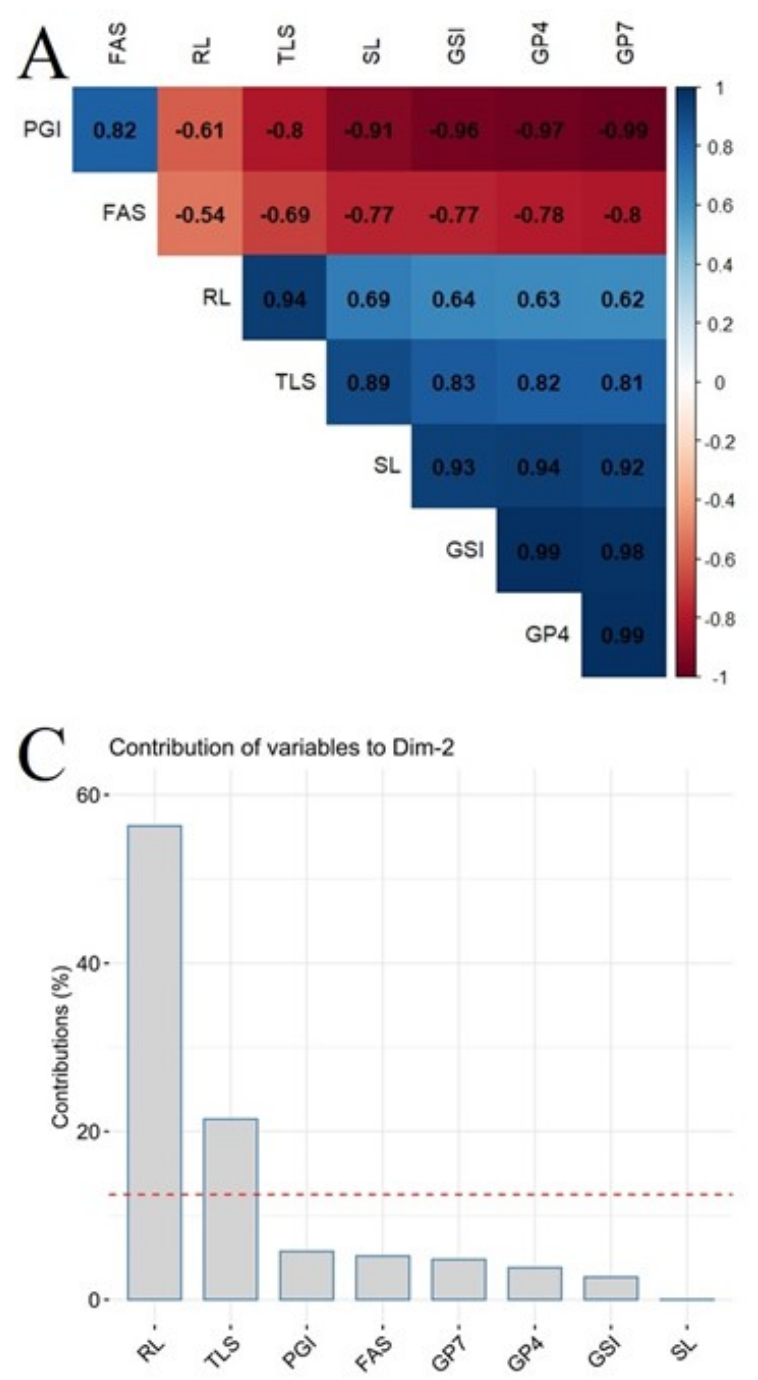

formed a single group (right quadrant of figure 1D), while all other variables formed another group in the opposite quadrant (quadrant Figure 1D).
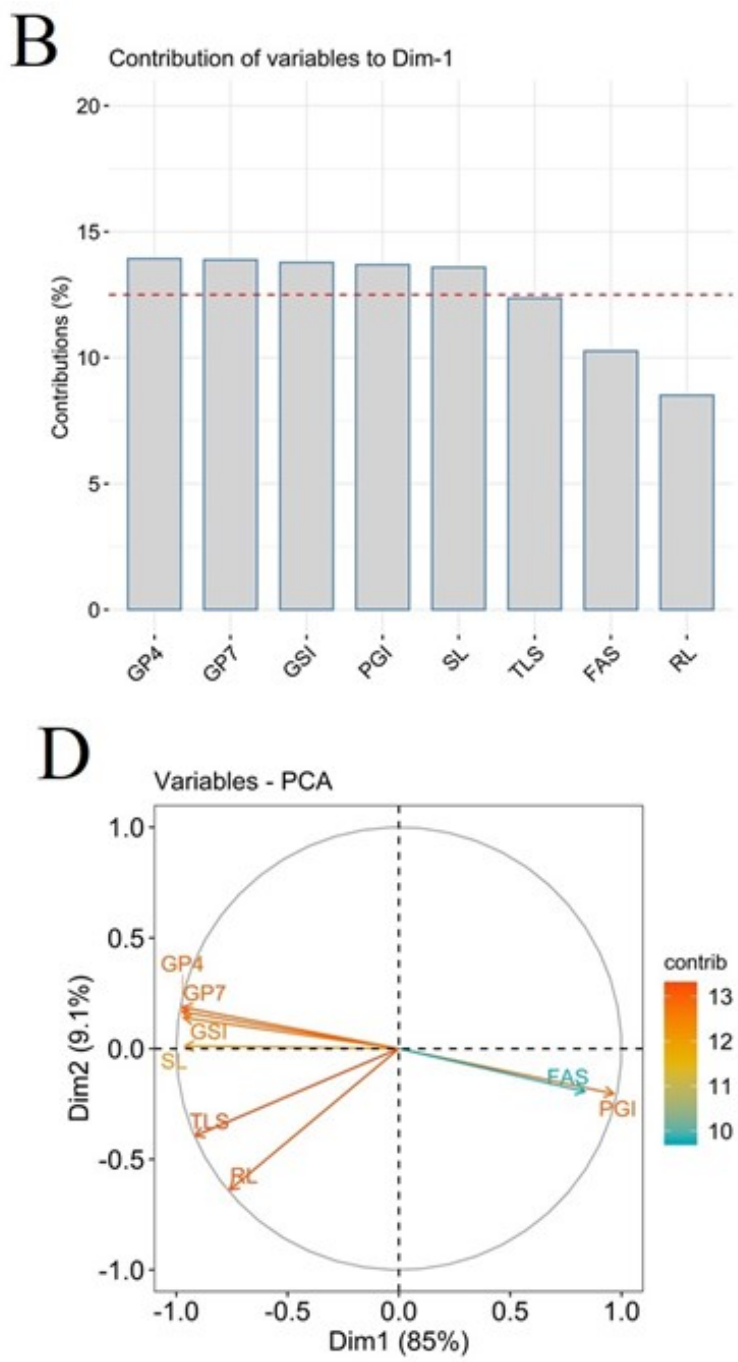

Figure 1 - (A) Pearson correlation analysis. Colored cells show significant correlations $(\mathrm{p}<0.01)$, (B) contribution of variables in the first principal component, (C) contribution of variables in the second principal component and (D) figure correlation of variables in the first and second principal component.

\section{DISCUSSION}

Extracts of pecan nut have several substances, such as phenolic and flavonoids compounds, which may be of interest to the chemical industry due to their potential biotechnological applications (Prado et al. 2014, Flores-Estrada et al. 2020). In some situations, the substances of interest to the chemical industry are precisely molecules that have the toxic potential on the germination of seeds of other plant species, since they could be applied in the control of weeds, for example (Islam and Widhalm, 2020). Here, plant extracts from leaves (LR) and fruit epicarp residues (ER) of pecan tree drastically reduced the lettuce seed germination, with inhibition of germination greater than $80 \%$. The same treatments reduced seed germination speed more markedly than extracts from heterogeneous pecan tree residues (HPR) and mesocarp residues (MR). Klein et al. (2017) also demonstrated that extracts obtained from pecan walnut residues can reduce the germination and germination speed of lettuce seeds, thus indicating the presence of allelochemical substances in aqueous extracts.

The results demonstrate that these effects depend 
on the pecan plant tissue used to obtain the extract. The leaves and epicarp of fruits probably have active concentrations of chemical compounds that have allelopathic effects on lettuce seed germination. Cosmulescu et al. (2011) observed that the leaf and green husk have high concentrations of allelochemical substances and phenolic compounds, substances that can be toxic to other plant species. However, this effect on lettuce germination (final germination count) is not observed for heterogeneous residues (HPR) and mesocarp residues (MR) used in the extracts. In this context, the application of pecan pruning residues as a substrate for the development of seedlings should be evaluated more carefully (Fermino et al., 2015).

In addition, LR and ER treatments reduced root length, hypocotyl length and total seedling length. However, the major effects for these variables was observed in plant extracts of epicarp residues (RE). For this same treatment, all germinated seeds developed in the development of not normal seedlings. These plant tissues - epicarp and leaves are likely to have higher concentrations of allelochemical substances, for example juglone. Juglone (5-hydroxy-1,4-naphtha-quinone) which is naturally found in the leaves, roots, and bark of plants in the Juglandaceae family, particularly in $C$. illinoinensis has been associated with a range of biological activities including increased activity of oxidative enzymes and reduction of seed germination (Terzi et al., 2003; Kocaçalikan et al. 2009; Bouali et al., 2018). Juglone is a quinoid compound that functions as an allelochemical and that has been isolated from several Juglandaceae members, including C. illinoinensis, and when taken up by sensitive plants, has general inhibitory effects on growth and development (Islam and Widhalm, 2020).

The correlation analysis showed that all variables related to seed germination are closely correlated. This demonstrates that the effect of any treatment applied to the seeds will affect all seed quality parameters. Still, our results reveal that the reduction in germination speed is closely related to the increase in the frequency of abnormal seeds, indicating that the longer the time for seeds to germinate, when submitted to a stimulus, the greater the probability of seedling development with morphophysiological disorders.

Our study showed that pecan tree wastes can decrease the lettuce seed germination. However, this effect depends on the plant tissue (e.g. leaf, epicarp, mesocarp) used in the production of plant extracts. Plant extracts from heterogeneous lignocellulosic residues and mesocarp residues do not result in drastic allelochemical effects. In contrast, aqueous extracts of leaf residues and epicarp residues significantly. The results are preliminary, other tests with different species of cultivated plants and weeds must be carried out to verify or effect these extracts on germination and seedlings. Moreover, in search of more specific two allelochemical elements present, the stability in environment and mechanism action needs to be investigated in more detail.

\section{CONCLUSION}

Plant extracts from leaf residues and epicarp residues from $C$. illinoinensis inhibit the germination and seedling development of L. sativa.

\section{REFERENCES}

Aslam F, Khaliq A, Matloob A, Tanveer A, Hussain S, Zahir ZA. Allelopathy in agro-ecosystems: a critical review of wheat allelopathy-concepts and implications. Chemoecology, v. 27, p. 1-24, 2017.

Brasil. Ministério da Agricultura, Pecuária e Abastecimento. Regras para análise de sementes. Brasília: Mapa/ACS. 2009, 399p.

Bouali I, Khadhri A, Dallali S, Albouchi A, Sebei H, Boukhchina S, Masson E. Chemical composition and antioxidant activity of essential oils from three varieties of Carya illinoinensis (Wangenh.) C. Koch Grown in Tunisia. Journal of Essential Oil Bearing Plants, v. 20, p. 1472-1481, 2018.

Bundchen AC, Santos GA, Prestes Junior HS, Furst JP, Schmidt IK, Klein C. Caracterização física de diferentes substratos para uso em floricultura. Anuário pesquisa e extensão UNOESC São Miguel do Oeste, v. 4, p. 1-7, 2019.

Cosmulescu SN, Trandafir I, Achim G, Baciu A. Juglone content in leaf and green husk of five walnut (Juglans regia L.) cultivars. Not. Bot. Hort. Agrobot. Cluj., v. 39, n. 1, 237-240, 2011.

Feng C, YongJie M, HaiWei S, XiaoFeng L, WenGuan Z, JianWei L, WenYu Y, Kai S. Effect of plant allelochemicals on seed germination and its ecological significance. Chinese Journal of Eco-Agriculture, v. 25, n. 36-46, 2017.

Fermino MH, Trevisan M, Busnello. Cascas de tungue e de noz pecan como alternativa de substrato para horticultura. Horticultura Brasileira, v. 33, p. 459-464, 2015.

Ferreira EB et al. ExpDes.pt: Pacote Experimental Designs (Portuguese). R package version 1.2.0., 2018. https://CRAN.R-project.org/package=ExpDes.pt

Flores-Estrada R, Gámez-Meza N, Medina-Juárez LA, Castillón-Campaña LG, Molina-Domínguez CC, Rascón-Valenzuela LA, García-Galaz A. Chemical composition, antioxidant, antimicrobial and antiproliferative activities of wastes from pecan nut [Carya illinoinensis (Wagenh) K. Koch]. Waste and Biomass Valorization, v. 11, p. 34193432, 2020.

Groth MZ, Ramos RF, Bellé C, Betemps DL, Andrade N, Kaspary TE. Bean seed performance under different 
temperatures. Journal of Biotechnology and Biodiversity, v. 8, p. $12-16,2020$

Islam AKMM, Widhalm JS. Agricultural uses of juglone: opportunities and challenges. Agronomy, v. 10, p. 1-9, 2020.

Junior APB, Magalhães LMS. Produção de mudas por estaquia, de acalifa e tumbérgia, utilizando compostagem, preparada a partir de resíduos da poda da arborização urbana. Revista da Sociedade Brasileira de Arborização Urbana, v. 5, n. 113-148, 2010.

Klein MI, Biondo E, Kolchinki EM, Sant'Anna V. Allelopathic effect of aqueous extracts from agro-industrial residues of pecan nut [Carya illinoinensis (Wangenh) C. Koch] and pinhão (Araucaria angustifolia). Revista Eletrônica Científica da UERGS, v. 3, p. 495-507, 2017.

Kocaçalikan I, Ceylan M, Terzi I. Effects of juglone on seedling growth in intact and coatless seeds of cucumber $(\mathrm{Cu}$ cumis sativus cv. Beith Alpha). Scientific Research and Essays, v. 4, p. 039-041, 2009.

Lima RLS, Severino LS, Ferreira GB, Sofiatti V, Sampaio LR, Beltrão NEM. Casca de mamona associada a quatro fontes de matéria orgânica para a produção de mudas de pinhão-manso. Revista Ceres, v. 58, n. 2, p. 232-237, 2011.

Mendiburu F. Agricolae: Statistical Procedures for Agricultural Research. R package version 1.3-1., 2019.

https://CRAN.R-project.org/package=agricolae

Nasser NPA, Ramos RF, Scheeren NB, Nora DD, Bellé C, Betemps, DL. Germinação de sementes de Bromelia antiacantha em diferentes fotoperíodos. Revista Eletrônica Científica da UERGS, v. 5, n. 3, p. 296-301, 2019.

Prado ACP, Silva HS, Silveira SM, Barreto PLM, Vieira CRW, Maraschin M, Ferreira SRS, Block JM. Effect of the extraction process on the phenolic compounds profile and the antioxidant and antimicrobial activity of extracts of pecan nut [Carya illinoinensis (Wangenh) C. Koch] shell. Industrial Crops and Products, v. 52, p. 552-561, 2014.

R Core Team. R: A language and environment for statistical computing. R Foundation for Statistical Computing, Vienna, Austria, 2019. URL https://www.R-project.org/.

Rehman S, Shahzad B, Bajwa AA, Hussain S, Rehman A, Cheema SA, Abbas T, Ali A, Shah L, Adkins S, Li P. Utilizing the allelopathic potential of brassica species for sustainable crop production: A Review. Journal of Plant Growth Regulation, v. 38, p. 343-356, 2019.

Rodrigues LA, Muniz TA, Samarão SS, Cyrino AE. Qualidade de mudas de Moringa oleifera Lam. cultivadas em substratos com fibra de coco verde e compostos orgânicos. Revista Ceres, v. 63, p. 545-552, 2016.

Santos S, Moraes MLL, Rezende MOO. Allelopathic potential and systematic evaluation of secondary compounds in extracts from roots of Canavalia ensiformis by capillary electrophoresis. Eclética Química, v. 32, p. 13-18, 2007.

Severino LS, Lima RLS, Beltrão NEM. Composição química de onze materiais orgânicos utilizados em substratos para produção de mudas. Comunicado Técnico, v. 278, p. 1-5, 2006.

Terzi I, Kocaqatiskan I, Benlioglu O, Solak K. Effects of juglone on growth of cucumber seedlings with respect to physiological and anatomical parameters. Acta physiologiae plantarum, v. 25, p. 353-356, 2003.

Vieira ACC, Terra DLCV, Souza PB, Fonseca EF. Utilização de resíduos agroindustriais na produção de mudas de aroeira (Myracrodruon urundeuva Fr. Allemão). Magistra, v. 30, p. 86-93, 2019.

Wei T, Simko VR package "corrplot": Visualization of a Correlation Matrix. Version 0.84, 2017. https://github.com/taiyun/corrplot

Wolff LF, Medeiros CAB. Alternativas para a diversificação da agricultura familiar de base ecológica -2017 . Documentos Embrapa Clima Temperado, v. 443, p. 1-145, 2017.

Wylot E, Ramos RF, Mello AM, Sobucki L, Dossin MF, Pavanelo AM. Germinação de sementes de Phaseolus vulgaris L. submetidas a diferentes tratamentos com bioestimulante. Revista Brasileira Multidisciplinar-ReBraM, v. 2, n. 1, p. 121-130, 2019. 